\title{
The Mysterious Domination of Food/Drinking Water Contaminants and Adulterants in Bangladesh
}

\section{A. K. Mohiuddin}

Department of Pharmacy, World University of Bangladesh, Dhaka, Bangladesh. Email:trymohi@gmail.com

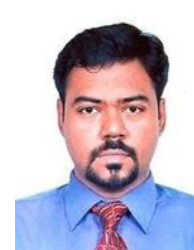

\begin{abstract}
Food adulteration and contamination is nothing new in this age. It is the consequence of modern civilization, people moving from places with altered social value and ethics, industrialization and rapid progression of economic activities. It is highly prominent in urban areas of many developed or underdeveloped countries and so is with in Dhaka city. Commercialism and business mind drive people toward such unethical activities knowingly or unknowingly. Most of the cases it is done by uneducated or illiterate people, having least idea about what evil they are doing to mankind. People who are health conscious mostly avoid these but many of them have to go with this because of the busy life schedule or carelessness. By definition, safe food or drink means pollutants or adulterants presence within the limit of the standard such as pathogenic micro-organisms, natural toxins and potentially harmful chemicals that may cause health hazards beyond a certain limit, either deliberately added or naturally present in them. Again, the economic development of the country doesn't reveal basic literacy and awareness of general people. Necessary steps should be taken by the authority and mass people should change their mind set up and have to avoid those who create harm. Purpose of the Study: Brief review of chemical induced food and drinking contamination, their consequences and control. Healthcare providers/Policy makers have a major role play to concerned field. Findings: Both general people and the old system, are responsible for this unlivable condition of Bangladesh. Population is not the sole for this instance. A sense of poor rules and regulation is always found everywhere. Negligence is becoming a wide spread disease contaminating illiterate to well educated, all kind of people.
\end{abstract}

Keywords: Carcinogen, Chemical intoxication, Food poisoning, Health hazard, Pathogen, Adulterants.

Citation | A. K. Mohiuddin (2019). The Mysterious Domination of Food/Drinking Water Contaminants and Adulterants in Bangladesh. Agriculture and Food Sciences Research, 6(1): 30-40. History:

Received: 9 January 2019

Revised: 18 February 9019

Revised: 18 February 2019

Accepted: 21 March 2019

Licensed: This work is licensed under a Creative Commons

Attribution 3.0 License $(\mathrm{cc})$ (

Publisher: Asian Online Journal Publishing Group
Funding: This study received no specific financial support.

Competing Interests: The author declares that there are no conflicts of interests regarding the publication of this paper.

Transparency: The author confirms that the manuscript is an honest, accurate, and transparent account of the study was reported; that no vital features of the study have been omitted; and that any discrepancies from the study as planned have been explained.

Ethical: This study follows all ethical practices during writing.

\section{Contents}

1. Introduction

2. Materials and Methods

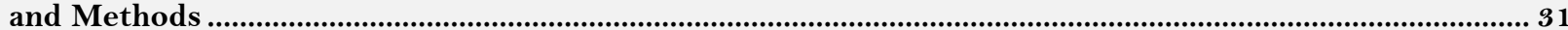

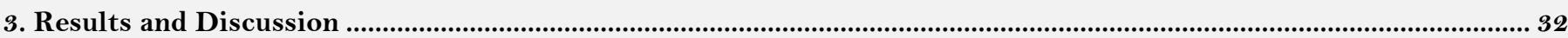

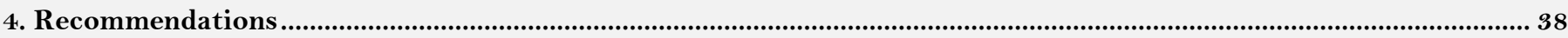

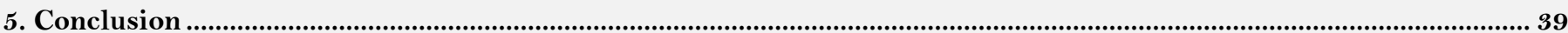

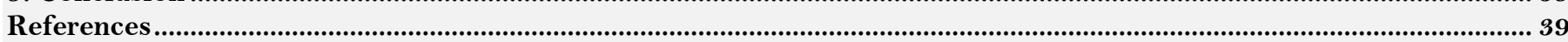




\section{Introduction}

Contamination is the presence of an unwanted substance where it should not be or at concentrations above recommended. Pollution is contamination that results in adverse biological effects to resident communities. Food contaminants and adulterants gave a new dimension in city life, together rest of the country. Rural people are less exposed to adulteration than urban people because of busy life, arrangement of food/spice item are mostly obtained from nearby grocery stores, chain shops and nearby open markets. Recent media reports on the malpractice in the food sector has revealed horrifying scenario leading to massive public outcry. Although there is no official statistics on food borne illness, it is perceived to be a major problem in urban areas of Bangladesh. Contaminated food, filthy and unhygienic environment of urban cities result in health hazard which may even cause deaths. The healthcare providers/policy makers' role in environmental health is related primarily to being alert to the conditions prevailing in the community and of working with others to adequately control any of the attendant hazards.

\section{Materials and Methods}

Comprehensive literature search followed by consulting healthcare professionals, Hospital, clinic associates, newspaper journalists, NGO workers about adulteration and food contamination. A few high officials were asked help for necessary books, journal, and newsletters. A few local magazine and newspapers also observed to get the necessary concern. Projections were based on various types of adulteration in food served/sold to general people, contaminated drinking water supply from a variety of sources.

\subsection{Gross Outcomes of Chemical Contamination}

Food remains a significant vehicle of disease organisms. Foodborne disease, more commonly but often incorrectly called "food poisoning," is grossly underreported. In most instances the illness produced by contaminated food is mild and of short duration, but more severe outbreaks (such as hepatitis A, most commonly seen in public restaurants) can occur. Epidemics of food-borne disease are dramatic and sudden, and most people become sick within 6 to 24 hours after consuming the contaminated foodstuffs. The epidemic pattern of food-borne disease presents differently from the gastrointestinal symptoms (e.g., nausea, vomiting, and diarrhea) induced by intestinal enteroviruses. The safety laws and regulations of Bangladesh are as given in Table 1. WHO published chemical exposure to toxic level is suspected to be involved in causing -

- Carcinoma

- Cardiovascular disease

- Kidney, liver dysfunction Hormonal Imbalance

- Premature birth

- Suppression of Immune system

- Impaired development of nervous system

- Mental health problems and

- Learning disabilities/Cognitive dysfunction

Table-1. Food Safety Laws and Regulations and Food Standards in Bangladesh.

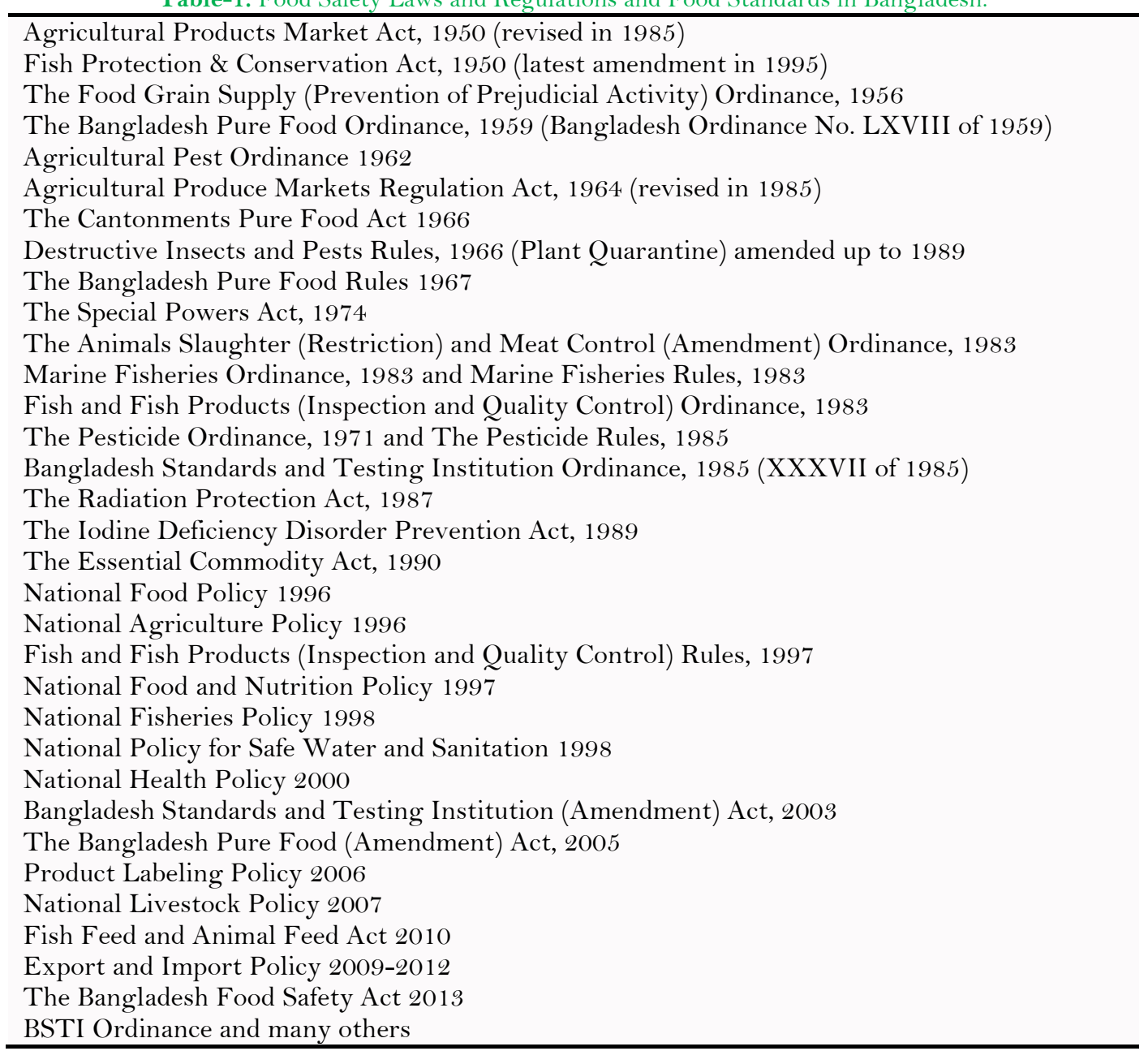




\subsection{Laboratories for Food Analysis}

- Public Health Laboratory (IPH)

- BSTI (Ministry of Industries)

- Food testing Laboratory (Ministry of Food \& Disaster management)

- Food testing Laboratory (Dhaka City Corporation)

- Institute of Food Radiation Biology, Bangladesh Atomic Energy Commission

- Institute of Food Science Technology, BCSIR

- Institute of Nutrition \& Food Science, University of Dhaka

\section{Results and Discussion}

Food adulteration is the most notorious enemy of mankind. Civilization has its own drawback that even causing destruction of itself. Very few people raised voice on this but crippled by the facts of commercialism. The scope of this article is limited to chemical food contaminants and adulterants. A few discussions based on real life experience and recent studies or reports from various journals and news articles are summarized here.

\subsection{Food and Supply Water Contamination}

Dhaka city, among huge amount of solid wastes per day from industrial discharge, fertilizers, fossil fuels, sewage sludge and municipality wastes and they are the major sources of heavy metals in soils and subsequent uptake by crops, vegetables and other food items causing serious health hazards to human beings [2-4]. A significant transfer of arsenic, cadmium, chromium, copper, lead, mercury, nickel, zinc, molybdenum and vanadium like heavy metals took place from soils to vegetables (spinach, tomato and cauliflower) grown in industrially polluted soils of Konabari at Gazipur and Keraniganj in Dhaka [5]. In the absence of effluent treatment plants (ETP), the factory wastes are drained out at will into the farmlands, and ultimately contaminate the farm produce. In our country we have allowed things like pollution and food contamination to run riot. Till now, no agency, either under the health ministry or the ministry of science and technology or the ministry of industries, has conducted any examination of the pesticide- residue levels or toxic chemicals in the foodstuff being marketed [6]. Apart from these, the slum areas are both populated and are in greatest risk of notorious pathogen found both in food sample and supplied water Table 2. According to Dhaka Water Supply and Sewerage Authority (DWASA), it can currently supply $75 \%$ of water demand, out of which $85 \%$ is from groundwater sources (Deep Tube wells). The presence of toxic metal lead in Elephant road, Dhaka University, Jatrabari, and Demra area and toxic Penta Chloro Phenol (PCP) and existing pathogenic bacterial load in the WASA supplied drinking water from different areas of Dhaka city were found to be unsuitable for human consumption Table 3.

\subsection{Arsenic Issue of Drinking Water}

Twenty million people in Bangladesh are still drinking water contaminated with arsenic, two decades after the potentially deadly toxin was discovered in the supply [7]. The Bangladesh government is failing to adequately respond to naturally occurring arsenic in drinking water across large areas of rural Bangladesh,

Table-2. Detection of Foodborne Pathogens in Food and Household Water Samples Collected at Point of Use from Four Slums of Dhaka City, Bangladesh, December 2015 To May 2016 [8]

\begin{tabular}{|c|c|c|}
\hline Presence of organisms in food/water & Overall & \\
\hline A. Organisms present in Food & n (\%) & $95 \% \mathrm{CI}$ \\
\hline Yeast and mould (>100 CFU/mg) & $48.0(85.7)$ & $0.74-0.93$ \\
\hline Coliforms (>100 CFU/mg) & $41.0(73.2)$ & $0.59-0.84$ \\
\hline B. cereus (>100 CFU/mg) & $27.0(48.2)$ & $0.35-0.62$ \\
\hline E. coli (>100 CFU/mg) & $17.0(30.4)$ & $0.19-0.44$ \\
\hline Staphylococcus (>100 CFU/mg) & $8.0(14.3)$ & $0.08-0.27$ \\
\hline V. cholera & $2.0(3.5)$ & $0.01-0.14$ \\
\hline B. Organisms present in Water & Overall $n=16 n(\%)$ & $\mathbf{9 5 \%} \mathrm{CI}$ \\
\hline Total coliforms & $16.0(100)$ & - \\
\hline Fecal coliforms & $16.0(100)$ & - \\
\hline Total aerobic bacterial count & $16.0(100)$ & - \\
\hline Yeast & $16.0(100)$ & - \\
\hline Mould & $16.0(100)$ & - \\
\hline Staphylococcus & $16.0(100)$ & - \\
\hline E. coli & $10.0(62.5)$ & $0.35-0.86$ \\
\hline Fecal streptococci & $9.0(56.3)$ & $0.29-0.79$ \\
\hline Pseudomonas & $7.0(43.8)$ & $0.21-0.71$ \\
\hline
\end{tabular}

Note: Total coliforms and fecal coliforms count (CFU/g).

Human Rights Watch said in a report. Approximately 20 years after initially coming to international attention, an estimated 20 million people in Bangladesh - mostly rural poor - still drink water contaminated over the national standard [11]. Bangladesh's health system largely ignores the impact of exposure to arsenic on people's health. An estimated 43,000 people die each year from arsenic-related illness in Bangladesh, according to one study [12]. The government identifies people with arsenic-related illnesses primarily via skin lesions, although the vast majority of those with arsenic-related illnesses don't develop them. Those exposed are at significant risk of cancer, cardiovascular disease, and lung disease as a result, but many receive no health care at all [13]. 
Table-3. Lead, Cadmium, Chromium and Arsenic content in first 14 water samples [9].

\begin{tabular}{c|c|c|c|c|c|c}
\hline $\begin{array}{c}\text { Sample } \\
\text { No. }\end{array}$ & Sampling Area & $\begin{array}{c}\text { Pb content } \\
(\mathbf{m g} / \mathbf{L})\end{array}$ & $\begin{array}{c}\text { Cd content } \\
(\mathbf{m g} / \mathbf{L})\end{array}$ & $\begin{array}{c}\text { Cr content } \\
(\mathbf{m g} / \mathbf{L})\end{array}$ & $\begin{array}{c}\text { As content } \\
(\boldsymbol{\mu g} / \mathbf{L})\end{array}$ & $\begin{array}{c}\text { Total Bacterial } \\
\text { Count c.f.u./ 100mL }\end{array}$ \\
\hline 1 & Dhaka University & O.52 & 0.05 & BDL & 0.78 & $4.0 \times 105$ \\
\hline 2 & Bangshal & BDL & 0.03 & BDL & 0.43 & $2.1 \times 104$ \\
\hline 3 & DMCH & BDL & 0.04 & BDL & 0.25 & $1.0 \times 104$ \\
\hline 4 & Basabo & BDL & BDL & BDL & 5.12 & $4.2 \times 106$ \\
\hline 5 & Komlapur & BDL & BDL & BDL & 0.21 & - \\
\hline 6 & Badda & BDL & 0.04 & BDL & 1.29 & $1.0 \times 105$ \\
\hline 7 & Sobujbagh & BDL & 0.04 & BDL & 0.42 & $5.2 \times 106$ \\
\hline 8 & Shagun Bagichaa & BDL & 0.06 & BDL & BDL & $5.0 \times 103$ \\
\hline 9 & Demra & O.46 & 0.07 & BDL & 0.44 & - \\
\hline 10 & Jatrabari & O.51 & 0.07 & BDL & 0.15 & $1.5 \times 104$ \\
\hline 11 & Mohammadpur & BDL & 0.07 & BDL & 0.53 & $5.0 \times 103$ \\
\hline 12 & Panthapath & BDL & 0.07 & BDL & 0.29 & $3.0 \times 104$ \\
\hline 13 & Elephant Road & O.53 & 0.08 & BDL & 0.10 & $2.5 \times 104$ \\
\hline 14 & Shampur & BDL & 0.08 & BDL & 0.56 & $3.5 \times 104$ \\
\hline Sourc & & & & & \\
\hline
\end{tabular}

\subsection{Food Adulterants}

Important food hazards include microbial hazards, pesticide residues, misuse of additives, chemical contaminants, including biological toxins and adulteration. Although microbiological contamination and chemical hazards have received most attention, it is recognized that food adulteration and food fraud should not be neglected considering their role in public health [14]. Food adulteration includes various forms of practices, such as mixing, substituting, concealing the quality of food by mis-labelling, putting up decomposed or expired food, and adding toxic substances [15]. About the proportion of adulterated food items in the market varied between $70 \%$ to $90 \%$. More than 76 percent food items in the market were found adulterated in a random survey by public health laboratory of Dhaka City Corporation in 2004 [16, 17].

According to the International Centre for Diarrheal Disease \& Research, Bangladesh (ICDDR, B), there is approximately 150 food items in the country. A study by the Institute of Public Health (IPH) revealed that more than $50 \%$ of the food samples they tested were adulterated. Textile dyes, which are highly injurious to health, are being randomly used to color many types of food. Textile dyes, which are highly injurious to health, are being randomly used to color many types of food [18]. Clay powder is mixed with the mixture of turmeric powder and cold toxic yellow dye to make it yellow. Water and salt are well mixed with these species to increase the weight. Mangoes, watermelon, litchi, watermelon, pineapple, papaya and bananas are artificially ripened using a carcinogenic chemical called ethylene oxide Table 4.

In bananas, another chemical called calcium carbide is used that becomes a spray Acetyl-gas to generate heat. Dalda (hydrogenated vegetable oil/ fat popular in South Asia) used in cooking is an example of a worst case false. "Our stomach temperature is 37 degrees Celsius and the melting point is 54 degrees Celsius Dalda. So, there is no way that Dalda can be absorbed by the body [19].

Most sweetened condensed milk products sold in the market actually contains palm oil which is used in substitute for cow's milk and therefore most sweetened condensed milks out there do not contain milk at all [20]. Fish is considered to be an essential protein for people of all ages. Many fish sellers spray fish with formalin in an indiscriminate manner, it makes the fish or fruits stiff and keeps them looking fresh for longer Table 5 . Undoubtedly human health is now under the possession of formalin, in our country about 400 tons formalin is being imported which are goes to human stomach, creates deadly mistreats on long term exposure Table 6, even though for laboratory or research purposes 100 tons of Formalin is quite enough, $80 \%$ of the imported formalin being added to food only for business purposes.

Three-fourths of the marketed vegetables, fruits, and fish contain pesticides and formalin residues. The consumption of such foods might lead to serious diseases [21]. Ironically even food color is being adulterated. Substandard food color is finding its way into many types of food. This includes the reddish jelapi, and the saffron beguni, peaju or alur chop. Candy, chips, ice cream, chewing gum and even biryani may contain large amounts of poor-quality food color. Cooking oil that is so commonly used to deep fry items should only be used once but many food vendors and restaurants recycle burnt oil. Once the oil is used for cooking, it becomes oxidised. The more the oil is used, the more pre-oxide is created which is really harmful for the body.

This gets more poisonous with continued usage. In 2017, police seized around 3,000 eggs suspected to be artificial during a raid in Patiya upazila, Chittagong. They also arrested two men - an egg shop owner and an egg supplier - suspected to be involved in the trade and marketing of fake eggs [24]. Doubt also pointed in rice also. The term 'plastic rice' was coined by the online media around 2010, when China reported its use for adulteration of a premium rice called Wuchang, which is known for its aroma [25].

The Institute of Public Health (IPH) in Dhaka and the World Health Organization (WHO) in their joint study on food adulteration in 1994 tested 52 street vendors and found that all of their food samples were contaminated with different types of pathogenic microorganisms. They also conducted another study in 2003 in Dhaka city and found that $96 \%$ of sweetmeats, $24 \%$ of biscuits, $54 \%$ of breads and $59 \%$ of ice creams Table 7 were extensively adulterated [26]. 
Table-4. Adulterants Used in Different Food Items of Vegetable Origin as Reported in Lay Press Reports [22].

\begin{tabular}{|c|c|}
\hline Food category and food item & Adulterant \\
\hline Edible oil & Argemone oil, mineral oil and rancid oil given commonly** \\
\hline $\begin{array}{l}\text { Soybean oil } \\
\text { Mustard oil }\end{array}$ & $\begin{array}{l}\text { Palm oil, chemical*, color*, burnt Mobil } \uparrow \text { from rail locomotives, burnt oil from electric } \\
\text { transformer Chemicals }\end{array}$ \\
\hline \multicolumn{2}{|l|}{ Food grain and grain products } \\
\hline $\begin{array}{l}\text { Lentils, mugdal, chola, mosurdal, } \\
\text { dabli, mashkolai, buter dal (lentil } \\
\text { types) }\end{array}$ & $\begin{array}{l}\text { Toxic coloring agents*, imported low-quality inedible lentils mixed with textile dye* and have } \\
\text { fungal growth; less expensive Mashkolai dal powdered with champa color* and sold as mugdal }\end{array}$ \\
\hline Rice & Urea added to make it whiter \\
\hline $\begin{array}{l}\text { Dhekichata chal (husked } \\
\text { rice), ata (course flour) }\end{array}$ & Red toxic color* mixed with rice and ata to sell as husked rice, red atta \\
\hline Muri (puffed rice) & Urea fertiliser to make it whiter and puffier \\
\hline Wheat, corn & Animal feed packaged as human food \\
\hline Semai (vermicelli) & Dalda made with rotten potato, cow intestine, low-quality palm oil \\
\hline \multicolumn{2}{|l|}{ Vegetables and tubers } \\
\hline Vegetables & Organophosphorus compounds and other pesticides \\
\hline Tomato & Calcium carbide for artificial ripening \\
\hline Potol (pointed gourd), peas & Textile dye* \\
\hline Eggplant & Pesticide* \\
\hline Green peas & Chemically colored* Dabli \\
\hline Potato & Red toxic color* \\
\hline \multicolumn{2}{|l|}{ Spices } \\
\hline Mixed spices (powder) & Brick dust, saw dust, chaler kura (dust from outer layer of rice) \\
\hline Turmeric powder & Brick dust, buter dal, kheshari dal (lentils), artificial powder, color \\
\hline Chili powder & Powder with color \\
\hline Coriander powder & Chaler kura (dust from outer layer of rice), toxic color* \\
\hline Zeera (cumin) powder & Brick dust, toxic color*, powder \\
\hline Pepper & Papaya seed \\
\hline Salt & No iodine \\
\hline \multicolumn{2}{|l|}{ Bakery products } \\
\hline Cake+t. & $\begin{array}{l}\text { Textile dye, chemicals*, inedible date expired ata/maida, fertiliser urea, substandard inedible } \\
\text { dalda, rotten egg }\end{array}$ \\
\hline Biscuitt+ & $\begin{array}{l}\text { Ammonium bicarbonate, sodium cyclamate, fertiliser urea, toxic coloring agents*, palm oil, } \\
\text { burnt oil, outdated inedible ata/maida }\end{array}$ \\
\hline Bread $_{+}^{+}$ & Rotten egg, outdated ata/maida \\
\hline Fruit and fruit products & (Lead arsenite, Calcium carbide, Ethephon, Formalin, Injection of dye in general) \\
\hline Mango, banana, pineapple & Calcium carbide for artificial ripening \\
\hline Cherry & Koromcha (Carissa carandas, Christ's thorn) with chemical color \\
\hline Orange and lychee juice & Water, flavor, textile dye*, sweet pumpkin, and color \\
\hline Imported juices & Substandard, date expired with new sticker \\
\hline \multicolumn{2}{|l|}{ Snacks } \\
\hline Noodles+ & Dhekichata chal, lal atta (coarse wheat flour), red potato \\
\hline Chanachur & Fried in burnt mobil $\uparrow$, no potato, imported powder, and color \\
\hline Peyaju, beguni & Toxic dye* \\
\hline \multicolumn{2}{|l|}{ Chocolate, sugar, and honey } \\
\hline Chocolate & Powder, sugar, color*, chemical \\
\hline Sugar & Soda used instead of sugar in food \\
\hline Honey & Sugar syrup \\
\hline \multicolumn{2}{|l|}{ Others } \\
\hline Pickle & Inedible ingredients \\
\hline Jorda (smokeless tobacco) & Wood dust, chemical \\
\hline $\begin{array}{l}\text { Mineral water and } \\
\text { drinking-water+ }\end{array}$ & $\begin{array}{l}\text { Tap-water, arsenic contaminated, contaminated with bacteria, no } \\
\text { mineral }\end{array}$ \\
\hline
\end{tabular}
drinking-water++

**Argemone oil leads to Epidemic dropsy, Loss of vision, Heart diseases, Tumor, Mineral oil cause liver damage and carcinogenic; Rancid oil leads destroys vitamin A and E

$\uparrow$ Polychlorinated biphenyl (PCB) used as coolant in automobiles and transformers;

+Prepared in unhygienic condition

\begin{tabular}{l|l}
\multicolumn{2}{c}{ Table-5. Underlying Reasons behind Adulteration Issue in Fish Supply Chain of Bangladesh [23]. } \\
\hline Reasons & Details \\
\hline $\begin{array}{l}\text { A cheap method to prevent Post harvest } \\
\text { Loss }\end{array}$ & $\begin{array}{l}\text { To prevent this post-harvest loss one of the cheap methods is to use formalin and other } \\
\text { toxic chemical which helps to keep this fish fresh for a long time. }\end{array}$ \\
\hline Lack of technical knowledge & $\begin{array}{l}\text { Lack of proper technical knowledge contributes in use of waste material in fish culture, } \\
\text { improper handling after post-harvest and use of formalin and other toxic elements. }\end{array}$ \\
\hline $\begin{array}{l}\text { Lack of ice box, unavailability of ice, high } \\
\text { price of ice, lack of cold store to keep } \\
\text { unsold fish. }\end{array}$ & $\begin{array}{l}\text { Ice/Icebox is expensive. Main problem in the market of Bangladesh is there is lack of cold } \\
\text { storage in the market place. As a result, there is no proper way to preserve unsold fish. }\end{array}$ \\
\hline Lack of awareness & $\begin{array}{l}\text { Most of the traders do not aware of the danger of using these harmful chemicals. On the } \\
\text { other hand, customers are also not properly aware of this issue. }\end{array}$ \\
\hline Lack of government initiative & $\begin{array}{l}\text { Co-ordination between authorities is a major issue, does not appear to be any cohesive } \\
\text { view regarding procedures and penalties for the same offence by officials from same } \\
\text { organisation. }\end{array}$ \\
\hline $\begin{array}{l}\text { Food laws and regulations are mostly outdated and fragmented. Even the new Safe Food } \\
\text { Act } 2013 \text { is not free from this as it is basically modeled on the Pure Food Ordinance of } \\
1959 .\end{array}$ \\
\hline $\begin{array}{l}\text { Considering the extent of harmfulness of food adulteration, penalties mentioned in law is } \\
\text { insufficient. For an example, the penalty for food adulteration is maximum term of six } \\
\text { months of imprisonment or up to a maximum fine of BDT 10o0 which is equivalent to } \\
\text { EUR 10.77. Considering the gravity of the offences this punishment is not hard enough. }\end{array}$ \\
\hline \begin{tabular}{l} 
Inadequate Penalties \\
\hline
\end{tabular}
\end{tabular}

Source: Fatema and Moslah [23]. 
Table-6. Effect of Formalin Treated Food Consumption on Health [23].

\begin{tabular}{l|l}
\hline Exposure routes & Effect on human \\
\hline Carcinogenicity & $\begin{array}{l}\text { Formalin has the potential effect to cause cancer, repeated and prolonged exposure increases the } \\
\text { risk of cancers of the lung, nasopharynx, oropharynx and nasal passage }\end{array}$ \\
\hline Reproductive health & It has a harmful effect on reproduction system by inducing oxidative stress. \\
\hline Skin (dermal) & $\begin{array}{l}\text { Prolonged and repeated contact with formalin could cause numbness (lack of feeling) and a } \\
\text { hardening or tanning of the skin }\end{array}$ \\
\hline Eye contact & $\begin{array}{l}\text { Formalin solution splashed in the eye can cause injuries from transient discomfort to severe such as } \\
\text { loss of vision }\end{array}$ \\
\hline \multicolumn{2}{l}{ Source: Fatema and Moslah $[23]}$.
\end{tabular}

Source: Fatema and Moslah [23].

Table-7. Adulterants Used in Different Food Items of Animal Origin as Reported in Lay Press Reports [22].

Food category and food item

\begin{tabular}{|c|c|}
\hline Hen egg** & $\begin{array}{l}\text { White eggs of farm hens colored red with textile dye* to sell as local hen eggs. Tortoise eggs sold as } \\
\text { hen eggs }\end{array}$ \\
\hline Fish & $\begin{array}{l}\text { Inject formalin through the gills or dip fishes in water treated with chemicals, such as chloro-fluoro } \\
\text { carbon (CFC); DDT } \psi \text { p powder to prevent rotting; add red color* to give fresh look; sell rotten fish }\end{array}$ \\
\hline Dry fish & DDTw \\
\hline Mutton & Buffalo, sheep and beef meat sold as mutton \\
\hline Beef & Buffalo meat sold as beef \\
\hline Halim $_{+}^{+}$ & Left over bones, intestine \\
\hline \multicolumn{2}{|c|}{ Sweetmeats and dairy products } \\
\hline Butter & Cow's intestine, dalda mixed with color*, powder* \\
\hline $\begin{array}{l}\text { Ghee, dalda } \\
\text { (hydrogenated } \\
\text { vegetable oil) }+\end{array}$ & Banaspati, toxic chemical*, potato smash, cow's fat, intestine \\
\hline Sweetened curd + & Textile dye* \\
\hline Sweetmeats + & $\begin{array}{l}\text { Textile dye named 'thousand power color' and toxic chemicals*; rotten eggs; dalda made with cow's } \\
\text { intestine, saccharin, soybean oil and vegetable oil instead of milk fat; paste of ground rice and } \\
\text { sulphuric acid mixed with milk to make posset }\end{array}$ \\
\hline $\begin{array}{l}\text { Jilapi (coil-like juicy } \\
\text { sweet) }\end{array}$ & Fried with Mobil \\
\hline Halua & Rotten carrot and lau (bottle gourd), chemical* \\
\hline Ice-cream+ & $\begin{array}{l}\text { Unsold foul-smelling ice-cream refined and re-packaged, almost no milk, } \\
\text { palm oil for soap manufacturing, textile dye*, low-quality milk powder, } \\
\text { sodium cyclamate }\end{array}$ \\
\hline $\begin{array}{l}\text { Imported milk } \\
\text { powder }\end{array}$ & Adulterated, low-quality, date expired, without BSTI approval \\
\hline \multicolumn{2}{|c|}{ Fast food and restaurant food $\psi$} \\
\hline Jelly, sauce & Toxic coloring agents*, chemicals*, spirit \\
\hline Chicken** & Dead chicken; cooked and raw meat refrigerated together \\
\hline Shrimp & Sold rotten \\
\hline Fish & Fried and raw fish refrigerated together \\
\hline
\end{tabular}

Consumption of adulterated food items may cause asthma, sore throat, larynx constriction, bronchitis, skin infections, allergic reactions, diarrhea, hematuria, circulatory failure, numbness, dizziness, kidney failure, stomach cancer, liver cancer, nervous disorders and many other diseases Table 8. After consumption of adulterated food items, thousands of people are becoming sick. Children are the worst victims. About three million people suffered from diarrhea during 2005-2009 and about 15\% of children died in 2011 as reported by the Directorate General of Health Services [27]. The long-term effects are also very severe especially the incidence of renal failure, liver damage and cancer which are increasing alarmingly in Bangladesh. Heavy metals, such as lead, chromium and arsenic accumulate in the body that might cause kidney and liver damage and develop abnormality among children. Indiscriminate and irrational use of antibiotics in poultry without following withdrawal period may result in unexpected residues in animal food and could cause serious health hazards to consumers. Research reports on antibiotic residues in broiler meat and liver from different farms and local markets for the presence of residues of ciprofloxacin, enrofloxacin, oxytetracycline, doxycycline and amoxicilin antibiotics revealed significant level of exposure of antibiotic residues. There's a greater chance of declining immunological responses and can detrimentally affect intestinal microbiota in susceptible individual. According to Prof. Muniruddin Ahmed (Clinical Pharmacy and Pharmacology, Dhaka University) Cooking cannot destroy antibiotic residues, which made them resistant to antibiotic treatment [28].

Milk in rural areas is usually adulterated with dirty water, which can cause hepatitis. People have now come to know about a new milk adulteration technique that uses a thickening agent, sorbitol, and detergent. ICDDR, B recent studies shows nearly $75 \%$ samples from primary-level producers were contaminated with coliform and more than $50 \%$ with fecal coliform bacteria. At the collection points, samples were found contaminated with a high number of coliform bacteria and fecal contamination of more than $90 \%$ while more than $40 \%$ of the samples had a high E coli count [29]. Vegetable and fruit samples collected from around Savar, Dhamrai and Tongi show the presence of textile dyes, which, in the short-term, will cause diarrhea, food poisoning and gastrointestinal problems, but in the long-term toxic materials will accumulate in the body with serious health implications [30]. In Bangladesh, people allowed things like pollution and food contamination to run riot. Till now, no agency, either under the health ministry or the ministry of science and technology or the ministry of industries, has conducted 
any examination of the pesticide- residue levels or toxic chemicals in the foodstuff being marketed. These merchants and traders are the enemy not only of the nation and their own children but of the entire mankind. The holy Prophet (PBUH) has disowned those who indulge in this immoral business. He said " The adulterator is not one of us" [31].

Table-8. Toxic Elements in Noxious Addition of Food/Additives with Possible Outcomes [17]; [22]; [29]; [16, 32-42]

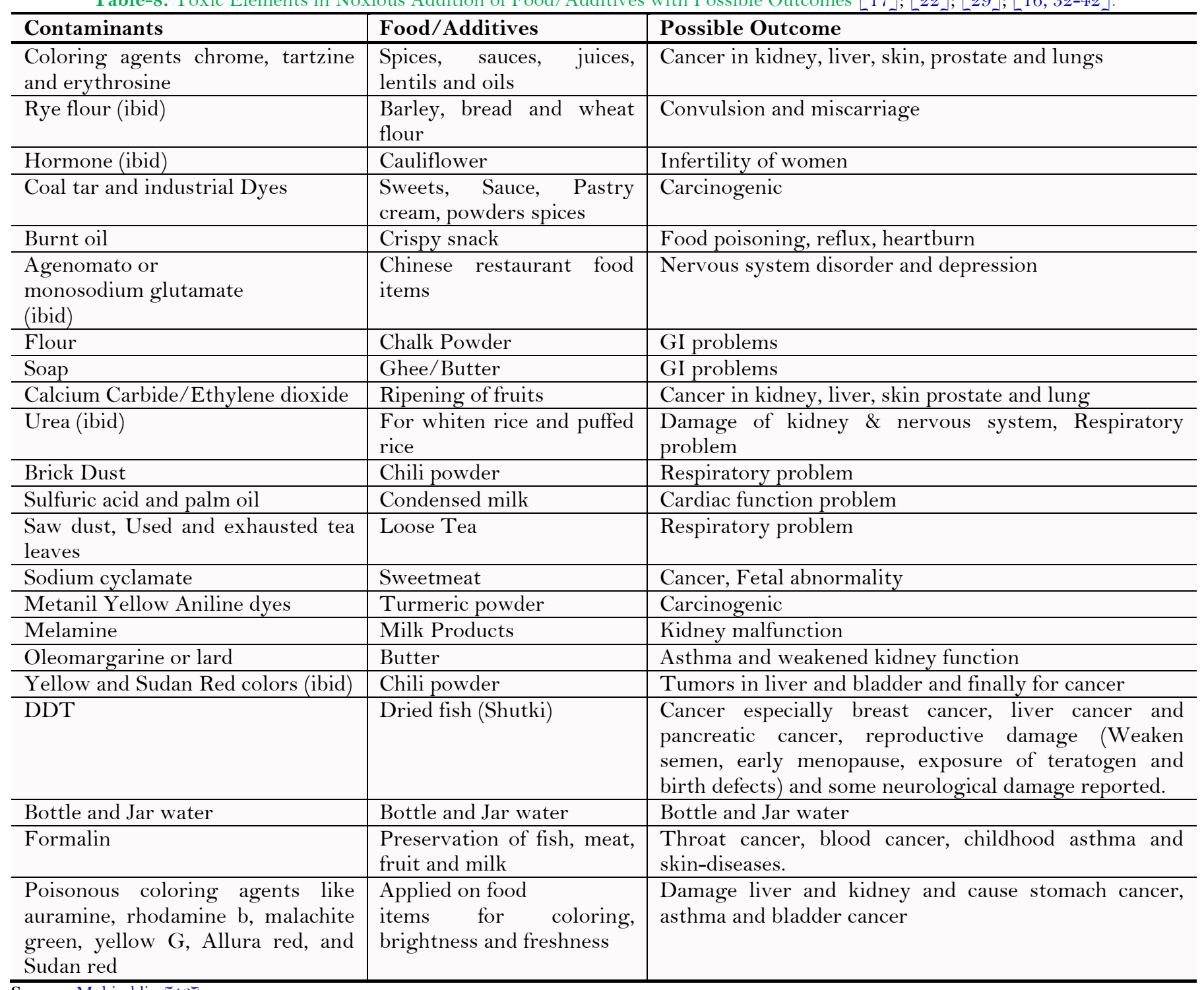

Source: Mohiuddin [42].

\subsection{Energy Drinks Vs Carbonated Drinks}

The government has decided to ban the production, marketing and import of energy drinks under the guise of carbonated beverages with immediate effect [43]. The Bangladesh Standard and Testing Institution (BSTI) at a council meeting on also resolved to take legal action against the companies that have been advertising their products as energy drinks after having them listed as carbonated beverages with BSTI. The move came after the Bangladesh Food Safety Authority (BFSA) wrote to BSTI to say the production of energy drinks in the name of carbonated beverages should not be allowed, as the ingredients of the two are significantly different. There is no government fixed standard for energy drinks in the country, Industries Minister told parliament once. Authority received complaints about the use of various highly addictive substances, including caffeine and opium, in energy drinks [44]. In 2012, a Department of Narcotics Control test conducted on energy drinks from several local and foreign companies had found excessive amount of artificial caffeine, Viagra (sildenafil citrate), beer and alcohol as ingredients [45]. The manufacture and advertising of energy drinks under a license for carbonated beverage is fraud, punishable under several laws including the BSTI Act and the Food Safety Act. Initially, the government will write to the companies to instruct them to discontinue their production and marketing of energy drinks. Punitive actions will follow if they do not comply, said the official. The government will also amend the import policy in order to blacklist the foreign energy drinks with harmful ingredients [46].

\subsection{Safety Issues of Bottled Water}

So-called mineral water supplied to houses and offices in jars are not tested. In most cases, the water is filled in the jars right away from the tap and sometimes in the empty bottles of some of the well-known mineral bottle brands [47]. The Bangladesh Agricultural Research Council (BARC) has of late made a sensational revelation regarding the quality of water different companies supply for drinking in and around Dhaka. According to the findings of the government study, 'coliform bacteria' (pathogens from feces of humans and animals) has been found in $97 \%$ of so-called filtered water supplied in jars to households, shops and offices in the capital city of Bangladesh. A team of BARC researchers determined the 'horrifying' data while studying the level of minerals in jars and bottled water marketed in Dhaka city. The researchers sampled 250 jars from across the city's Farmgate, Karwan Bazar, Elephant Road, New Market, Chawk Bazar, Sadarghat, Keraniganj, Jatrabari, Motijheel, Basabo, Malibagh, Rampura, Mohakhali, Gulshan, Banani, Uttara, Airport, Dhanmondi, Mohammadpur, Mirpur, Gabtoli, and on the city's outskirts at Aminbazar, Savar and Ashulia. The level of 'coliform bacteria' in the samples collected from 
Elephant Road, Chawk Bazar, Basabo, Gulshan and Banani areas was found significantly high in the research [21]; [48]. A few months ago, a mobile court busted six fake mineral water plants in Bosila area of Dhaka's Mohammadpur and sentenced six staffers to different terms of jail. The team also seized 2000 jars of water and destroyed those later [49].

\subsection{Food Adulteration during Ramadan}

The crime of those selling adulterated and unhygienic food items is very serious and strict action needs to be taken as per law against such guilty persons. According to media reports some 600 field-level sanitary inspectors are working across the country to ensure food safety for all during the holy month of Ramadan. This is welcome news but if previous records are anything to go by people should not get their hopes up too high. Even more unfortunate is the fact that this nefarious practice increases exponentially during the month of Ramadan. It was found that coloring agents are used in spices, sauces, juices, lentils and oils. Formalin and carbide used in fish, fruit, meat and milk [50]. The shopkeepers and the merchants many of them with a pious fade try to earn a large amount of profit by this unethical practice, and so they play with the life and health of the people. They mix dangerous things in the daily eatables.

\subsection{Sub-Standard Vermicelli (Shemai) and Cow Fattening Ahead of Eid}

Adulterated vermicelli flooded different markets in the capital ahead of Eid-ul-Fitr, one of the biggest religious festivals of the Muslims, posing a serious threat to public health. A section of unscrupulous businessmen is busy in manufacturing sub-standard vermicelli in the port city ahead of Eid-ul-Fitr as the food item has a high demand in the day. According to local sources, some of the factories are using unrefined palm oil and animal fat to produce Laccha vermicelli while hazardous chemicals and toxic color were also used to make the food items. Bangla vermicelli is produced using flour and water and Laccha is produced with oil, flour sugar and water. Most cases, the vermicelli was being dried in unhygienic condition in the rooftop of the factories [51]. Seeking anonymity, a seasonal vermicelli maker said a section of businessmen in the city bought the adulterated vermicelli and sell them tagging labels of renowned companies. BSTI personnel left a comment as Bangla vermicelli is used to make by seasonal factory for a certain time, it is not mandatory to take license from BSTI, however, the factory should take health and hygienic certificate issued by the Sanitary Inspector [52, 53]. With Eid-ul-Azha around the corner, the Poribesh Bachao Andolon (Poba) has recently urged the government to monitor how cattle is being reared and fattened in the farms in the country [54]. Knowingly causing such damage to public health in order to hike up the price of cows is a crime, and must be dealt with swiftly. The use of antibiotics, growth hormones, harmful chemicals, and steroids is prohibited by the Animal Feed Act 2010. Violators may be faced with a year in prison, a Tk 50,000 fine, or both. A large number of farmers involved in bull fattening just before 3 or 4 months of Eid-UlAzha (Muslim festival), when they sell the animals with profitable price. Visiting different villages in Bera, Santhia and Ataikula upazilas of Pabna, and Shahjadpur and Baghabari areas in Sirajganj, these correspondents found that almost every household was using steroids, antibiotics and other chemicals for months in blatant violation of law. Everyone -- from cattle farm owners to landless farmers -- wanted to take full advantage of this. These cattlefattening drugs are also widely used in Chuadanga, Jhenidah, Nilphamari, Barisal, Faridpur, Manikganj and some other districts. Consumption of meat of these animals poses serious health risks for humans, according to experts [55]. The changes to the cow caused by these injections are not merely cosmetic - severe health damage is done to humans by the consumption of this meat. While most traders would still claim that the fattening supplements were not harmful, there is reason to believe these chemicals may cause cancer, kidney disease, and infertility in women $[56]$.

\subsection{Penalty Imposed on Famous Eateries}

Isn't it surprising that like many occasional drives against various crimes, the fight against unsafe food, too, has assumed the character of a seasonal activity? While this should have been a continuous and unrelenting activity round the year across the country, sporadic and infrequent moves here and there, leave no permanent impact on the sellers and producers of spurious food items of all varieties. Newspaper reports say that the drive against food adulteration is currently on in the capital, launched last week. The Bangladesh Food Safety Authority (BFSA), the state watchdog to regulate the sector is reportedly monitoring the capital's food markets under the supervision of an executive magistrate. One has reasons to question the rationale behind the drive in the capital alone, that too with just one magistrate. The effectiveness of the drive is bound to cause nothing more than a ripple with mobile courts punishing a few sweetmeat shops, restaurants and if at all, some kitchen market sellers. The fact that such drives, sporadic and half-hearted, failed to bring any discipline in the country's food market cannot be disputed. However, famous eateries/food chains are not devoid of these cases of adulteration and substandard food staffs. Penalty imposed on these famous shops/food chain should at least give an idea to general people that paying high price is not always an indicator of good quality. Even a few of them were penalise more than once or twice for the same reason but substandard food serves never ended Table 9. For a better view references regards are attached in this table with date published.

Government officials monitoring food markets in capital Dhaka fined businesses millions of BDT only after finding that their food items contained ingredients harmful to human health. Inadequate monitoring of food markets may have exposed people's health to serious hazards from consumption of substandard and adulterated foods. In the absence of corrective measures, punishing the offenders-at times by way of hefty monetary penalties-is not an appropriate method of dealing with the problem. A properly institutionalized mechanism with sufficient manpower and regular monitoring round the year can only bring things to some semblance of order. In this regard, it is important that the BSFA and other agencies such as the BSTI and the city corporations which also run such drives maintain a well-coordinated plan of action. It is also important that punitive actions should be backed by actions to improve the quality and standard of food of all varieties. To monitor the situation, inspection and sudden raids are welcome, but it must not be forgotten that inspection is just one of the many ways to rein in food adulteration. 
Table-9. Eateries/Chain Shops Raid List for Adulteration/Substandard Food Serving.

\begin{tabular}{|c|c|c|c|}
\hline Eateries/Super Shops & Possible Reasons/Issues & Reference & $\begin{array}{c}\text { Date } \\
\text { Published }\end{array}$ \\
\hline Khushbu Biriyani, Gulshan & Textile dyes for coloring Biriyani & $\begin{array}{l}\text { Daily Sun \& Daily } \\
\text { Bangladesh }\end{array}$ & $\begin{array}{c}29.05,18 \& \\
28.05 .18 \\
\end{array}$ \\
\hline 'Kosturi Restaurant, Gulshan & $\begin{array}{l}\text { unhygienic environment inside the } \\
\text { restaurant. }\end{array}$ & UNB News & 28.05 .18 \\
\hline Swapno’s Banani & Date-expired food & Daily Sun & 29.05 .18 \\
\hline $\begin{array}{l}\text { KFC, American Burger, Dawat-e Mejban, United } \\
\text { Catering, Dynamic Food Court, Dhanmondi }\end{array}$ & Rotten and unhealthy foods & Daily Sun & 29.05 .18 \\
\hline Meenabazar’s Shantinagar & $\begin{array}{l}\text { Soda water without the BSTI approval } \\
\text { and other issues. }\end{array}$ & Daily Sun & $29.05,18$ \\
\hline Agora and Nandan Super shop & $\begin{array}{l}\text { Selling different local and foreign } \\
\text { products having no BSTI approval. }\end{array}$ & Daily Sun & $29.05,18$ \\
\hline Boomers Café, Baily Road & $\begin{array}{l}\text { keeping food in unhygienic } \\
\text { environment }\end{array}$ & Daily Sun & $29.05,18$ \\
\hline SBARRO Cafe & $\begin{array}{lllll}\begin{array}{l}\text { keeping } \\
\text { approval. }\end{array} & \text { sauce } & \text { without } & \text { a } & \text { BSTI } \\
\end{array}$ & Daily Sun & $29.05,18$ \\
\hline Kutumbari Restaurant, Chittagong & Preserving date-expired fish and meat. & DhakaTribune & 28.06 .16 \\
\hline Bonoful Sweets, Chittagong & $\begin{array}{l}\text { Harmful ammonia for making biscuits } \\
\text { crispy. }\end{array}$ & DhakaTribune & 28.06 .16 \\
\hline Sizzle, Chittagong & $\begin{array}{l}\text { Applying color in making cakes which } \\
\text { is unfit for human consumption }\end{array}$ & DhakaTribune & 28.06 .16 \\
\hline $\begin{array}{l}\text { Flavor Sweet and Bakers and Fulkoli Food } \\
\text { Products, Chittagong }\end{array}$ & $\begin{array}{l}\text { Date-expired food colour in } \\
\text { manufacturing cake and sweetmeat. }\end{array}$ & DhakaTribune & 28.06 .16 \\
\hline Fakhruddin Biryani, Baily Road & $\begin{array}{l}\text { Using expired and rotten ingredients } \\
\text { for making Kebab and Halim }\end{array}$ & The News Today & 06.02 .18 \\
\hline 'Mr Bakers, Turag Area & $\begin{array}{l}\text { Preserving date-expired and stale cake } \\
\text { and making biscuits and toasts without } \\
\text { BSTI license. }\end{array}$ & The Daily Sun & 16.06 .17 \\
\hline Arabians Sweets and Bakery & $\begin{array}{l}\text { For not writing manufacturing and } \\
\text { expiry dates on their packets. }\end{array}$ & The Daily Sun & 16.06 .17 \\
\hline 'Pusty Dairy and Bakery, Malibagh & $\begin{array}{l}\text { For not taking BSTI license for } \\
\text { producing curd. }\end{array}$ & The Daily Sun & 16.06 .17 \\
\hline 'Lucky Vermicelli Factory' at Matuail in Jatrabari & $\begin{array}{l}\text { Making vermicelli in an unhygienic } \\
\text { environment. }\end{array}$ & The Daily Sun & 16.06 .17 \\
\hline $\begin{array}{l}\text { Yammi Yammi' and 'Ujjal Food Products' at } \\
\text { Pallabi, Mirpur }\end{array}$ & $\begin{array}{l}\text { Making food items in an unhygienic } \\
\text { manner }\end{array}$ & The Daily Sun & 16.06 .17 \\
\hline $\begin{array}{l}\text { New Food Hotel and Restaurant, Shibganj Sweets, } \\
\text { Tuhin Food Hotel, New Bidyut Hotel, Tripti Hotel } \\
\text { and Cafe RAJ Hotel, Memory Biriani House, Amir } \\
\text { Ali Fish Shop in Rajshahi City }\end{array}$ & Selling stale and adulterated foods & The Daily Star & 17.09 .18 \\
\hline Maloncho Restaurant at the New Elephant Road & Poor Hygiene & DhakaTribune & 25.07 .15 \\
\hline $\begin{array}{l}\text { Food Corner, Kings Fast Food, Penji Fast Food, } \\
\text { Kepray Fast Food, Capital Fast Food, Al Amin } \\
\text { Food, Saikat Fast Food, Welcome Fast Food and Al } \\
\text { Jaber Fast of Newmarket, Dhaka }\end{array}$ & Selling unhygienic food. & $\begin{array}{l}\text { United News of } \\
\text { Bangladesh UNB } \\
\text { Beta }\end{array}$ & 20.05 .18 \\
\hline KFC' \& Boomers Baily Road & $\begin{array}{l}\text { Serving expired and chemical-mixed } \\
\text { food items. }\end{array}$ & DhakaTribune & 25.07 .15 \\
\hline Pizza Hut, Baily Road & $\begin{array}{l}\text { Using chemicals in two of its popular } \\
\text { sauces without the authority's } \\
\text { approval. }\end{array}$ & DhakaTribune & 25.07 .15 \\
\hline $\begin{array}{l}\text { Chandrima Restaurant and Mini Chinese, Kasturi } \\
\text { Chhayanir and Thai Chinese Restaurant and New } \\
\text { Star Kebab }\end{array}$ & $\begin{array}{l}\text { Preserving and selling unhygienic food } \\
\text { items }\end{array}$ & $\begin{array}{l}\text { The Independent \& } \\
\text { Daily Prothom Alo }\end{array}$ & $\begin{array}{c}19.06 .17 \& \\
18.06 .17\end{array}$ \\
\hline Dawar-E-Mejban, Dhanmondi & $\begin{array}{l}\text { Using harmful chemicals to color } \\
\text { foods. }\end{array}$ & NEWAGE & 25.05 .18 \\
\hline $\begin{array}{l}\text { Ma-Moni Hotel and Restaurant, Suprema } \\
\text { Restaurant, Kosturi Restaurant, Rangpur City }\end{array}$ & $\begin{array}{l}\text { Preserving foodstuffs in unhygienic } \\
\text { and dirty environment }\end{array}$ & $\begin{array}{l}\text { BSS News and } \\
\text { Bangladesh Post }\end{array}$ & 26.09 .18 \\
\hline Agora, Shwapno and Meena Bazar Chittagong & For selling rotten meat and fish & Bdnews24.com & 11.06 .16 \\
\hline Meena Bazar, Agora, Swapna Dhaka & For selling low-grade packed products. & Bdnews24.com & 09.04 .12 \\
\hline $\begin{array}{l}\text { Agora, Meena Bazar and fast food chain Coopers, } \\
\text { Shantinagar }\end{array}$ & $\begin{array}{l}\text { For keeping expired and stale food } \\
\text { items } \\
\text { (rotten fish, meat and expired food } \\
\text { items) }\end{array}$ & $\begin{array}{l}\text { The Daily Star and } \\
\text { The Independent }\end{array}$ & $\begin{array}{l}15.05 .16 \& \\
11.05 .16\end{array}$ \\
\hline $\begin{array}{l}\text { Agora in Prabartok, The Grocer, and Khulshi Mart } \\
\text { in Khulshi, Meena Bazar in Sholoshahar and } \\
\text { Shwapno in Gol Pahar Chittagong }\end{array}$ & $\begin{array}{l}\text { Selling products at hiked up prices and } \\
\text { also selling rotten and stale items }\end{array}$ & The Daily Star & 11.06 .16 \\
\hline $\begin{array}{l}\text { Platinum Suites, King's Confectionary, Kobe } \\
\text { Restaurant, Pizza Inn }\end{array}$ & Selling expired, stale and rotten foods. & Bdnews24.com & 02.06 .18 \\
\hline $\begin{array}{l}\text { Disney Dine Restaurant Kabab Jangson Limited } \\
\text { Nababi Bhoj Solution Lounge, Shamoli }\end{array}$ & $\begin{array}{l}\text { Selling adulterated food items in } \\
\text { unhygienic conditions }\end{array}$ & DhakaTribune & 18.05 .18 \\
\hline Mir Al-Amin Hotel and Sharif Hotel & $\begin{array}{l}\text { Producing food items in an unhygienic } \\
\text { condition during Ramadan }\end{array}$ & Daily Sun & 19.06 .17 \\
\hline $\begin{array}{l}\text { Alauddin Sweetmeat, Royal Restaurant Lalbagh, } \\
\text { Star Hotel and Kabab, Voot Restaurant, Ambala } \\
\text { Sweetmeat, Iftari Bazar and Dominous Pizza in } \\
\text { Dhanmondi }\end{array}$ & $\begin{array}{l}\text { Using illegal food colorings, poisonous } \\
\text { chemicals and used cooking oil in } \\
\text { Ramadan }\end{array}$ & The Daily Star & 29.05 .12 \\
\hline
\end{tabular}

Source: Mohiuddin [42].

\section{Recommendations}

While contamination of food may be due to negligence, deliberate adulteration by toxic chemicals or radioactive materials for long shelf life of products and increasing the volume in size and weight-among the many crooked methods-is so rampant that it is difficult to find anyone who does not encounter an unpleasant moment of 
food-related illness at least once a year. Taking care of the situation thus calls for a whole package of initiatives. In advanced countries this involves producing, handling, storing and preparing foods in such a way as to prevent infection and contamination in the entire chain. However, in situations prevailing in this country, it is not merely about maintaining a clean chain but putting in strong deterrents so that criminality in the business could be stopped. Sources of harmful stuffs must be plugged, if necessary, by way of ban on imports or local production. Strong advocacy on the detrimental effects of consumption should be routinely done. At the same time, training on safe and scientific methods of preservation of food products should also be a high priority in an attempt to curb adulteration. Adulteration and contaminant control are a never ending, on the other hand a continuous process. It will increase with time as the civilization go ahead. Pharmacists should be aware of the local occupations, companies, and factories and to be cognizant of the initial symptoms of disease. Again, pharmacists should become acquainted with the local community and to adapt the principles of health and medical care to the particular situations encountered. The pharmacist's continuing education requirements should include watching the local pattern of society and its diseases, and changing the emphasis toward evolving disease patterns and their control. Government and regulatory authorities are to play strong role in controlling food contaminants and adulteration.

\section{Conclusion}

With constant change to the physical, biological, cultural, social, and economic environment, both healthcare providers and citizens should cultivate an informed awareness of these changes, and health providers should adapt their methods of health education, disease prevention, and disease control to the changes in each community. This is especially true food daily consumed, which require concerted community action for their control, but providers may play a much more fundamental and personal role in controlling food-borne diseases; often, the first indication of an outbreak of food-borne disease is time-limited, with an unusually large number of people seeking relief from health hazards. The necessary role in environmental health is related primarily to being alert to the conditions prevailing in the community and of working with others to adequately control any of the attendant hazards. Government related authorities, NGOs and other private organizations (e.g. Pharmaceutical companies) should take initiatives further to ameliorate food and drinking water situation which is worst among all other previous times. General people should be aware of these facts of mischiefs and take necessary steps on their own. A yearround campaign regarding these issues in public places, electronic media and even in rural areas can bring a change as brought by diarrhea, Vitamin A campaigns back in 70's and 80's.

\section{Abbreviations}

BDL (Below Detection Limit); BSTI (Bangladesh Standards and Testing Institution); BCSIR (Bangladesh Council of Scientific and Industrial Research); ICDDR, B (International Centre for Diarrheal Disease Research, Bangladesh); ETP (Effluent Treatment Plants); IPH (Institute of Public Health); DDT (Dichloro-DiphenylTrichloroethane); BFSA (The Bangladesh Food Safety Authority); BARC (Bangladesh Agricultural Research Council).

\section{References}

[1] S. Nasreen and T. Ahmed, "Food adulteration and consumer awareness in Dhaka City, 1995-2011," Journal of Health, Population, and Nutrition, vol. 32, pp. 452-464, 2014.

[2] M. Hashem, M. Nur-A-Tomal, M. Abedin, and S. Bushra, "Heavy metal assessment of polluted soil around Hatirjheel Lake of Dhaka city, Bangladesh," Bangladesh Journal of Scientific and Industrial Research, vol. 52, pp. 61-66, 2017. Available at: https://doi.org/10.3329/bjsir.v52i1.32084.

[3] I. Mahmudul, Toxicity of heary metals in soils and crops and its phyto-remediation dissertation for Phd department of soil. Dhaka-10oo: Water and Environment University of Dhaka, 2015.

[4] R. Ashiqur, J. S. Afroze, K. Bashar, M. F. Ali, and M. R. Hosen, "A comparative study of heavy metal concentration in different layers of tannery vicinity soil and near agricultural soil," American Journal of Analytical Chemistry, vol. 7, pp. 880-889, 2016. Available at: https://doi.org/10.4236/ajac.2016.712075.

[5] M. R. Islam, "Consumption of unsafe foods: Evidence from heavy metal, mineral and trace element contamination," Doctoral Dissertation, Bangladesh Agricultural University, Mymensingh, 2013.

M. K. Asadullah, "Bitter truth rampant adulteration still a havoc," The Daily Star, 2011.

O. J. Eresh, "World water day taking responsibility for our future," The Daily Star, 2017.

M. Ishita, N. N. Naila, M. Mahfuz, M. Roy, A. S. Faruque, and T. Ahmed, "Children living in the slums of Bangladesh face risks from unsafe food and water and stunted growth is common," Acta Paediatrica, vol. 107, pp. 1230-1239, 2018. Available at: https://doi.org/10.1111/apa.14281.

[9] S. Murshed, A. Hasan, F. M. Omor, and C. Subhagata, "Analysis of WASA supplied drinking water around Dhaka City from laboratory analysis perspective," International Journal of Chemical \& Physical Sciences, vol. 2, pp. 20-27, 2013.

[10] M. Sabrina, A. M. Hasan, F. M. Omor, and C. Subhagata, "Analysis of WASA supplied drinking water around Dhaka City from laboratory analysis perspective," International Journal of Chemical ङ Physical Sciences, vol. 2, pp. 20-27, 2013.

[11] P. Richard, "The politics of arsenic-free water," DhakaTribune, 2017.

[13] Human Rights Watch, "Nepotism and neglect the failing response to arsenic in the drinking water of Bangladesh's rural poor," Human Rights Watch, 2016

FAO/WHO, FAO/WHO expert consultation. Food protection for urban consumers. Rome: Food and Agriculture Organization, 1986. K. Park, Park's textbook of preventive and social medicine, 18th ed. Jabalpur: Banarsidas Bhanot, 2005.

Staff Correspondent, "Food adulteration rings alarm bell STAR-RDRS roundtable told most food items adulterated, pose lethal risks to public health," The Daily Star, 2011.

[17] F. Mirza, "Evaluating position of Bangladesh to combat 'adulterated food'crisis in light of human rights," IOSR Journal of Humanities and Social Science, vol. 19, pp. 45-54, 2014 . Available at: https://doi.org/10.9790/0837-19364554. OP-ED, "OP-ED. Public health issues in Bangladesh the independent " 2018.

M. A. Aasha and S. R. Avik, "Eating away our health cover story star weekend magazine," vol. 4, 2004.

N. Qyshalini, "A doctor reveals that condensed milk contains more sugar than actual milk! Web goodtimes," 2017.

K. H. Zubair, "Time to end food adulteration," The Daily Star, 2018.

N. Sharifa and T. Ahmed, "Food adulteration and consumer awareness in Dhaka City, 1995-2011," Journal of Health, Population and Nutrition, vol. 32, pp. 452-464, 2014.

[23] T. Fatema and M. Moslah, "Economic reasons behind adulteration issues in fish supply chain in Bangladesh," Journal of Business Studies, vol. 37, pp. 145-157, 2016.

[24] S. I. Ashif, "Govt: There's no such thing as fake eggs in market Dhakatribune," 2017. 
[25] Express, "The new Indian express. Plastic rice! Are you serious?," 2017

[26] S. M. Rahman, M. A. Hoque, and M. R. A. Talukder, "Food security in Bangladesh: Utilization, nutrition and food adulteration," presented at the Paper Presented at the National Workshop on Food security, Dhaka, Bangladesh, 19-20 October 2005$), 2005$.

D. K. Nath, "Food or poison? Bdnews24.com," 2014.

H. Emran, "Antibiotics-fed poultry pose threat to public health NEWAGE Bangladesh," 2016.

NewsDesk, "NewsDesk. Over $75 \%$ pasteurised milk unsafe for direct consumption in Bangladesh: ICDDR, B study. bdnews24.com," 2018

M. K. Asadullah, "Slow poisoning continues unabated," The Daily Star, 2010

Editorial, "Editorial. Food adulteration. The independent," 2017.

K. L. Zubair, A. Mohiuddin, and M. Bake, "Food contaminants: Bangladesh perspective Reference Id: PHARMATUTOR-ART1570," 2013.

33] S. Mohammad, "Heavy metal' in imported fish: Samples sent for retest," The Daily Star, 2018

[34] R. M. Arifur, M. Z. Sultan, M. S. Rahman, and M. A. Rashid, "Food adulteration: A serious public health concern in Bangladesh," Bangladesh Pharmaceutical Journal, vol. 18, pp. 1-7, 2015. Available at: https://doi.org/10.3329/bpj.v18i1.23503.

T. Nishat, "Food adulteration: A serious health risk for Bangladesh. risingbd.com," 2017.

N. Abu, "Food safety and public health issues of Bangladesh," European Food and Feed Law Review, pp. 31-40, 2013.

M. Nehreen, M. Real, M. Akter, and H. Azam, "Food adulteration and bio-magnification of environmental contaminants: A comprehensive risk framework for Bangladesh," Frontiers in Environmental Science, vol. 4, p. 34, 2016. Available at: https://doi.org/10.3389/fenvs.2016.00034.

[38] R. Shafkat, "Letters to the editor urea in puffed rice. The Daily Star August 27, 2013 Richard P. The politics of arsenic-free water," DhakaTribune, 2017.

[39] K. Rajib, "Cover unsafe food unhealthy life," Daily Sun, 2015.

[40] Editorial, "Editorial. Look for the flies- the future ahead!," Bangladesh Journal of Medicine, vol. 25, pp. 40-41, 2014.

$[41] \quad$ M. Mahboob, "Food adulteration: The Bangladesh paradox," Law Journal Bangladesh, vol. 2, 2015.

[42] A. Mohiuddin, "Chemical contaminants and pollutants in the measurable life of Dhaka City," European Journal of Sustainable Development Research, vol. 3, p. emo083, 2019. Available at: https://doi.org/10.29333/ejosdr/5727.

[43] Business, "Business, staff reporter. Manufactures seek help to dispel doubts about beverages. The Independent," 2018.

Staff, "Staff correspondent. No standard fixed for energy drinks Amu tells JS," The Daily Star, 2015.

S. I. Ashif, "The dangers lurking in your energy drinks," DhakaTribune, 2017.

S. I. Ashif, "Energy drinks cannot be sold as carbonated drinks Dhakatribune," 2017.

M. A. Joynul, "What are we drinking: Water or poison? Daily Sun," 2018

M. Sarwar, "How safe is bottled water for drinking? The financial express," 2018

Online, "Online Report 6 fake mineral water plants busted in Dhaka, 6 jailed The Daily Star," 2018

U. Ahamed, "Food adulteration rampant consumers urge continuous drive against the menace daily sun," 2018.

U. Ahamed, "Substandard vermicelli floods city markets," The Daily Sun, 2018.

F. Mizanur, "Sub-standard vermicelli manufactured ahead of Eid. ," DhakaTribune, 2016.

S. Solaiman, "Adulterated vermicelli floods markets," The Daily Sun, 2017.

Editorial, "Monitor cattle fattening Proper planning can make the difference this time. The daily Star," 2018.

R. Pinaki and A. Kabir, "Cow fattening out of control traders cut long process short with help of harmful drugs," The Daily Star, 2015.

[56] Tribune Editorial, "Put a stop to unethical cow-fattening practices. DhakaTribune," 2016. 